\title{
Endoplasmic Reticulum Stress Cooperates in Silica Nanoparticles-Induced Macrophage Apoptosis via Activation of CHOP-Mediated Apoptotic Signaling Pathway
}

\author{
Fenglei Chen ${ }^{1,2, *}$, Jiaqi Jin ${ }^{1,2}$, Jiahui Hu ${ }^{1,2}$, Yujing Wang ${ }^{1,2}$, Zhiyu Ma ${ }^{1,2}$ and Jinlong Zhang ${ }^{1,2}$ \\ 1 College of Veterinary Medicine, Yangzhou University, Yangzhou 225009, Jiangsu, China; \\ savannahkini@163.com (J.J.); Alohahujiahui@163.com (J.H.); Pluto7107@163.com (Y.W.); \\ mzy2017@yzu.edu.cn (Z.M.); zjl@yzu.edu.cn (J.Z.) \\ 2 Jiangsu Co-innovation Center for Prevention and Control of Important Animal Infectious Diseases and \\ Zoonoses, Yangzhou 225009, Jiangsu, China \\ * Correspondence: flchen@yzu.edu.cn; Tel.: +86-514-8797-9030
}

Received: 15 October 2019; Accepted: 18 November 2019; Published: 21 November 2019

check for updates

\begin{abstract}
While silica nanoparticles (SiNPs) have wide applications, they inevitably increase atmospheric particulate matter and human exposure to this nanomaterial. Numerous studies have focused on how to disclose SiNP toxicity and on understanding its toxic mechanisms. However, there are few studies in the literature reporting the interaction between endoplasmic reticulum (ER) stress and SiNP exposure, and the corresponding detailed mechanisms have not been clearly determined. In this study, CCK-8 and flow cytometry assays demonstrated that SiNPs gradually decreased cell viability and increased cell apoptosis in RAW 264.7 macrophage cells in dose- and time-dependent manners. Western blot analysis showed that SiNPs significantly activated ER stress by upregulating GRP78, CHOP, and ERO1 $\alpha$ expression. Meanwhile, western blot analysis also showed that SiNPs activated the mitochondrial-mediated apoptotic signaling pathway by upregulating BAD and Caspase-3, and downregulating the BCL-2/BAX ratio. Moreover, 4-phenylbutyrate (4-PBA), an ER stress inhibitor, significantly decreased GRP78, CHOP, and ERO1 $\alpha$ expression, and inhibited cell apoptosis in RAW 264.7 macrophage cells. Furthermore, overexpression of CHOP significantly enhanced cell apoptosis, while knockdown of CHOP significantly protected RAW 264.7 macrophage cells from apoptosis induced by SiNPs. We found that the CHOP-ERO1 $\alpha$-caspase-dependent apoptotic signaling pathway was activated by upregulating the downstream target protein ERO1 $\alpha$ and caspase-dependent mitochondrial-mediated apoptotic signaling pathway by upregulating Caspase-3 and downregulating the ratio of BCL-2/BAX. In summary, ER stress participated in cell apoptosis induced by SiNPs and CHOP regulated SiNP-induced cell apoptosis, at least partly, via activation of the CHOP-ERO1 $\alpha$-caspase apoptotic signaling pathway in RAW 264.7 macrophage cells.
\end{abstract}

Keywords: silica nanoparticles; endoplasmic reticulum stress; apoptosis; $\mathrm{CHOP}$

\section{Introduction}

Following the rapid development of nanotechnology, the potential harmful health effects of nanomaterial have aroused the public's widespread attention during the past decades [1,2]. Due to the unique physicochemical properties of nanoparticles (NPs), they can reach various tissues and organs in the whole body, and penetrate the body's protective barriers, such as the blood brain barrier, to increase the risk of toxicity to humans and animals. Among these NPs, silica nanoparticles (SiNPs) are a popular inorganic material for engineered nanoparticles. SiNPs have been extensively developed 
for chemical, materials, cosmetics, food, and biomedical applications, such as disease diagnosis, drug delivery, cancer therapy, and new types of animal vaccine preparations [3-5]. The wide application of SiNPs inevitably increases air pollutants. A previous study found that $\mathrm{Si}$ is a component with one of the highest contents in ambient fine particulate matter (PM 2.5) [6]. With the larger specific surface area and the higher particle number, SiNPs can adsorb much higher concentrations of pollutants and aggravate air pollution, and be easily exposed to humans through inhalation, ingestion, skin contact, and even vein injection [7-9]. SiNPs are currently on the priority lists for toxicological evaluation by the Organization for Economic Cooperation and Development (OECD) [10]. It is a prerequisite for the application of SiNPs to fully disclose its toxicity and deeply understand its toxic mechanisms.

In recent years, the toxicological studies of SiNPs showed that one of the most common toxic mechanisms is that SiNPs can produce excessive reactive oxygen species (ROS) in the body. Previous studies demonstrated that SiNPs induced cytotoxicity and oxidative stress through glutathione depletion and ROS generation in human bronchoalveolar carcinoma-derived cells (A549), human bronchial epithelial cells (Beas-2B), RAW 264.7 macrophage cells, myocardial H9c2(2-1) cells, renal proximal tubular cell lines (human HK-2 and porcine LLC-PK1), and human keratinocyte cells (HaCaT) [11-17]. Further studies demonstrated that SiNPs induced hepatocellular carcinoma cell line (HepG2) apoptosis through mitochondrial pathway mediated oxidative stress due to excessive ROS production [18-20]. Other than oxidative stress, excessive ROS affects endoplasmic reticulum (ER) homeostasis leading to ER stress. ER stress is induced by various pathophysiological conditions, such as the production of excessive ROS, the accumulation of misfolded or unfolded proteins, and the imbalance of intracellular $\mathrm{Ca}^{2+}$. To restore ER function, ER stress activates molecular chaperones in the ER, such as glucose-regulated protein 78 (GRP78), CCAAT/enhancer binding protein homologous protein $(\mathrm{CHOP})$, and ER oxidoreduclin $1 \alpha(\mathrm{ERO} 1 \alpha)$. GRP78 shows a marked upregulation in ER chaperones in response to ER stress [21]. However, severe or prolonged ER stress will trigger cell apoptosis. CHOP, as an apoptotic transcriptional factor induced by ER stress, is an essential marker for the assessment of ER stress-induced apoptosis [22].

At present, numerous studied have reported that ER stress cooperated in SiNP-induced apoptosis. Christen et al. reported that SiNPs could induce perturbations of the ER, leading to an ER stress response in human hepatoma cells (Huh7) [23]. Yang et al. found that SiNPs caused intracellular $\mathrm{Ca}^{2+}$ to increase, leading to intrinsic apoptosis in neuroblastoma SH-SY5Y cells via the CytC/Apaf-1 pathway [24]. ER stress activated SiNPs and oxidized low-density lipoprotein (oxLDL)-induced RAW 264 macrophage cells apoptosis, and the PERK signaling pathway cooperated in this process [25]. ER stress-mitochondria-mediated apoptotic pathways promoted SiNP-induced human umbilical vein endothelial cell (HUVEC) apoptosis, of which CHOP and XBP-1 were upregulated [10]. PERK and ATF6-mediated ER stress was validated to regulate SiNP-induced autophagy via the upregulation of downstream ATF4 and CHOP in hepatocytes [26]. ER stress cooperated in SiNP-induced apoptosis in human pulmonary alveolar epithelial cells (HPAEpiC) [27]. IRE1 $\alpha$-mediated ER stress activated SiNP-induced human endothelial cell (EC) apoptosis [28]. However, only a few literatures reported the interaction between ER stress and SiNP exposure, and the corresponding detailed mechanisms have not been clearly determined. Therefore, in the current research, we studied the effects on ER stress of using RAW 264 macrophage cells in vitro in order to gain insight into the potential toxicity and molecular mechanisms of SiNPs.

\section{Results}

\subsection{Silica Nanoparticle (SiNP) Characterization and Cell Viability and Apoptosis in RAW 264.7 Macrophage Cells}

SiNPs used in this study were near-spherical, porous, and unmodified. The diameter of SiNPs determined by TEM was 5-15 nm (Figure 1A), which was consistent with the size provided by the manufacturer. SiNPs usually displayed good dispersity in solution, although aggregates could be 
observed. Furthermore, to detect the electrical property of SiNPs, the result showed that SiNPs were electronegative in water, and the zeta potential was measured as $-9.9 \pm 1.1 \mathrm{mV}$.

The toxic effects of SiNPs on RAW 264.7 macrophage cells were examined by exposure to 0-200 $\mu \mathrm{g} / \mathrm{mL}$ SiNPs for 12 and $24 \mathrm{~h}$. The effects of SiNPs on cell viability were assessed using the CCK-8 assay. SiNPs significantly reduced cell viability of RAW 264.7 macrophage cells at different doses for 12 and $24 \mathrm{~h}$ in dose- and time-dependent manners (Supplementary Materials, Figure S1A; Figure 1B). The results of flow cytometry analysis revealed that the apoptotic rate of the cells was significantly different when exposed to 0,50,100, and $150 \mu \mathrm{g} / \mathrm{mL}$ SiNPs in a dose-dependent manner for 12 and 24 h (Supplementary Materials, Figure S1B,C; Figure 1C,D).

A

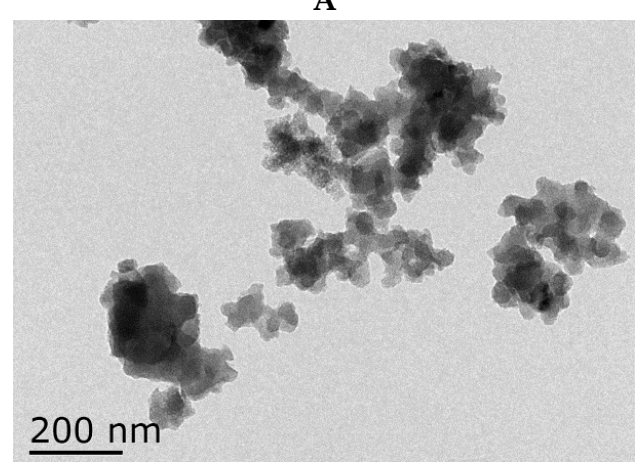

C

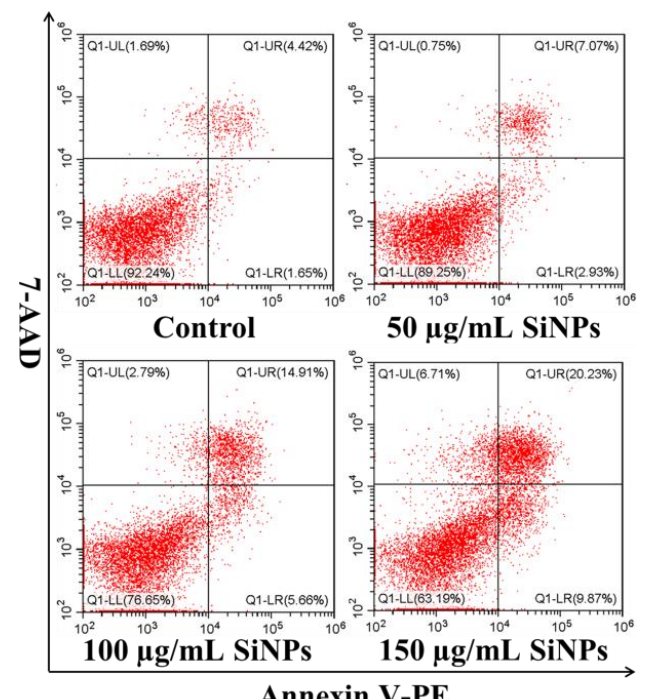

B

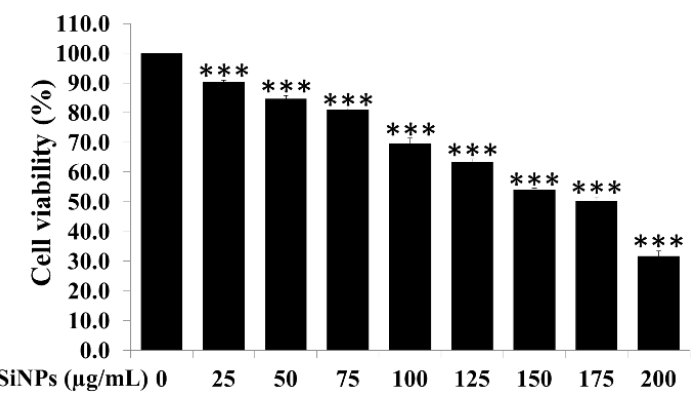

D

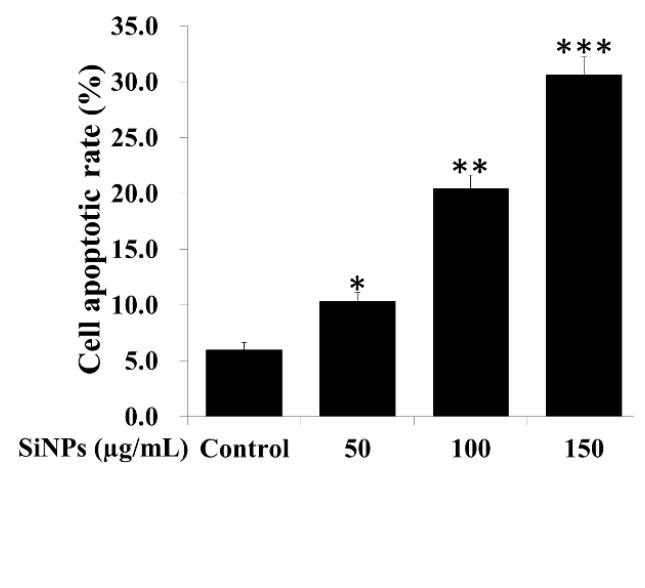

Figure 1. Silica nanoparticles (SiNPs) decreased cell viability and induced cell apoptosis in RAW 264.7 macrophage cells. (A) Representative TEM image of SiNPs used in the current work. Scale bar, $200 \mathrm{~nm}$. (B) SiNPs reduced cell viability of RAW 264.7 macrophage cells in a dose-dependent manner. Cells were treated with $0,25,50,75,100,125,150$, and $200 \mu \mathrm{g} / \mathrm{mL} \mathrm{SiNPs}$ for $24 \mathrm{~h}$, and then processed via the CCK-8 assay. (C,D) Cell apoptosis was detected via flow cytometry analysis. After exposure to 0, 50, 100, and $150 \mu \mathrm{g} / \mathrm{mL}$ SiNPs for $24 \mathrm{~h}$, RAW 264.7 macrophage cells were collected for Annexin $\mathrm{V}-\mathrm{PE} / 7-\mathrm{AAD}$ staining. UL quadrant is the part of cell death caused by mechanical damage or necrotic cells, UR quadrant is the part of late apoptotic cells, LL quadrant is the part of the normal cells, and LR quadrant is the part of early apoptotic cells. The number of cell apoptosis included the part of LR quadrant (early apoptotic cells) and UR quadrant (late apoptotic cells). The statistical analysis is shown in the bar graph. Data are presented as the mean \pm SDM of three independent experiments. Statistically different from the control is marked with asterisks $\left({ }^{*} p<0.05,{ }^{* *} p<0.01\right.$, and $\left.{ }^{* * *} p<0.001\right)$. 
2.2. Effect of SiNPs on the Expression of Endoplasmic Reticulum (ER) Stress-Related Proteins in RAW 264.7 Macrophage Cells

To investigate whether ER stress was activated in SiNP-induced apoptosis, the expression of the ER stress-related proteins GRP78, CHOP, and ERO1 $\alpha$ were determined in SiNP-exposed RAW 264.7 macrophage cells via western blot analysis. The result showed that SiNPs significantly upregulated the expression of GRP78, CHOP, and ERO1 $\alpha$ after exposure to 0, 50, 100, and $150 \mu \mathrm{g} / \mathrm{mL} \mathrm{SiNPs}$ for $12 \mathrm{~h}$ (Figure 2A,B). We also detected the expression of GRP78, CHOP, and ERO1 $\alpha$ at different times $(0,6,12$, and $24 \mathrm{~h}$ ) after exposure to $100 \mu \mathrm{g} / \mathrm{mL}$ SiNPs. The result also showed that GRP78, CHOP, and ERO1 $\alpha$ were upregulated, especially for CHOP and ERO1 $\alpha$ in a time-dependent manner (Figure 2C,D).
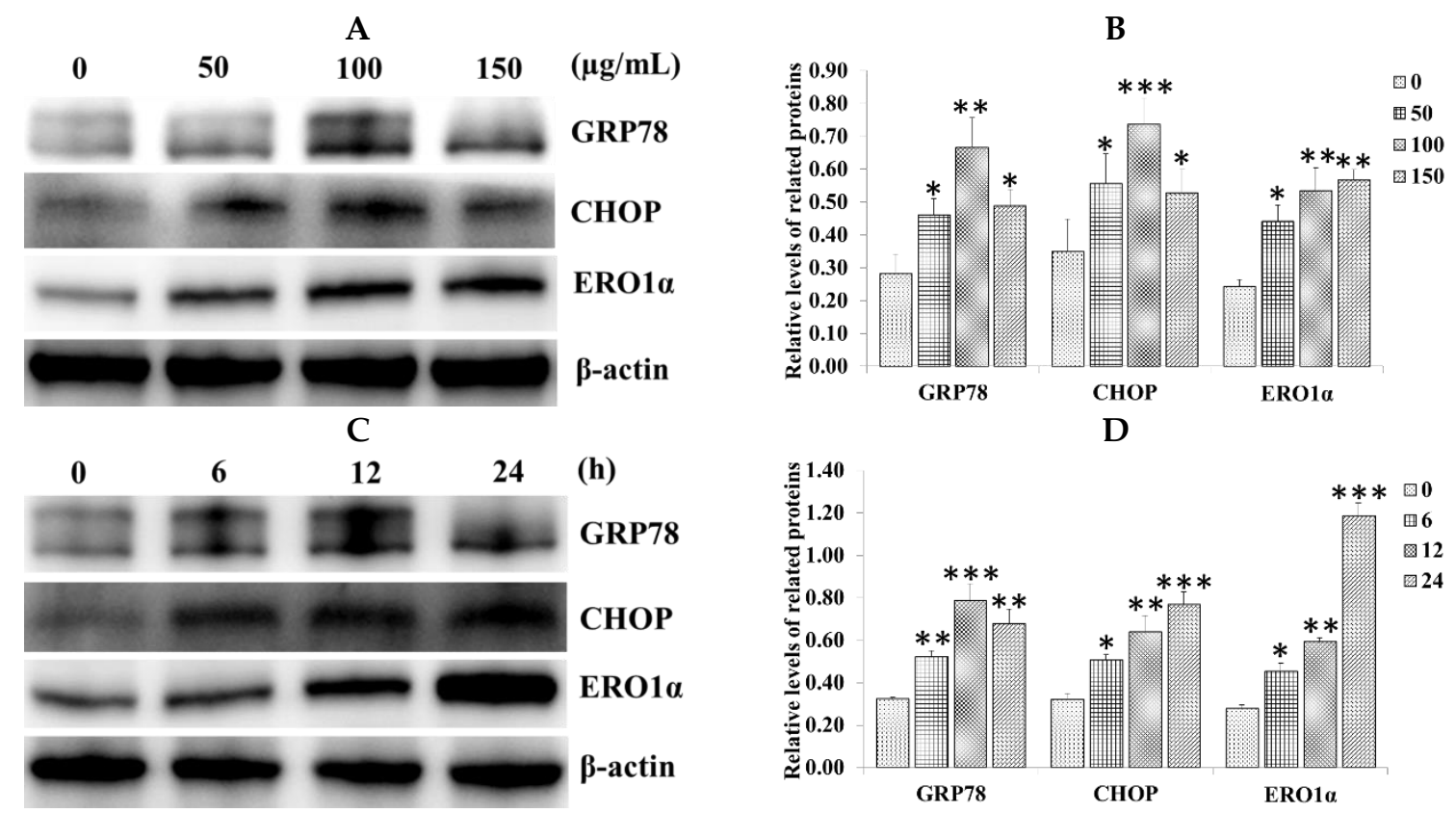

Figure 2. SiNPs induced the expression of the endoplasmic reticulum (ER) stress-related proteins in RAW 264.7 macrophage cells. (A,B) The expression of glucose-regulated protein 78 (GRP78), CCAAT/enhancer binding protein homologous protein (CHOP), and ER oxidoreduclin $1 \alpha($ ERO1 $\alpha)$ was analyzed via western blot analysis. Cells were exposed to different concentrations of SiNPs $(0$, 50, 100, and $150 \mu \mathrm{g} / \mathrm{mL}$ ) for $12 \mathrm{~h}$; (C,D) Cells were exposed to different times $(0,6,12$, and $24 \mathrm{~h}$ ) with $100 \mu \mathrm{g} / \mathrm{mL}$ SiNPs. Analyses of the band intensity on the films are presented as the relative ratio of the related proteins to $\beta$-actin. Statistical analysis is shown in the bar graphs. Data are presented as the mean \pm SDM of three independent experiments. Statistically different from the control is marked with asterisks $\left({ }^{*} p<0.05,{ }^{* *} p<0.01\right.$, and $\left.{ }^{* * *} p<0.001\right)$.

\subsection{Effect of SiNPs on the Expression of Apoptosis-Related Proteins in RAW 264.7 Macrophage Cells}

To determine whether the mitochondrial apoptotic signaling pathway was also activated, the B-cell lymphoma 2 (BCL-2) family members and Caspase-3 were detected in SiNP-exposed RAW 264.7 macrophage cells via western blot analysis. The result showed that SiNPs significantly upregulated the expression of the proapoptotic protein BCL-2-associated death promoter (BAD) and cleaved Caspase-3, while they downregulated the ratio of BCL-2/BCL-2-associated $\mathrm{X}$ protein (BAX) after exposure to $0,50,100$, and $150 \mu \mathrm{g} / \mathrm{mL}$ SiNPs for $12 \mathrm{~h}$ in a dose-dependent manner (Figure $3 \mathrm{~A}, \mathrm{~B}$ ). We also detected the expression of BCL-2, BAX, BAD, and cleaved Caspase- 3 at different times $(0,6,12$ and $24 \mathrm{~h}$ ) after exposure to $100 \mu \mathrm{g} / \mathrm{mL}$ SiNPs. The result also showed that BAD and cleaved Caspase-3 were upregulated, especially for cleaved Caspase-3 in a time-dependent manner, while the ratio of BCL-2/BAX was downregulated (Figure 3C,D). 
A

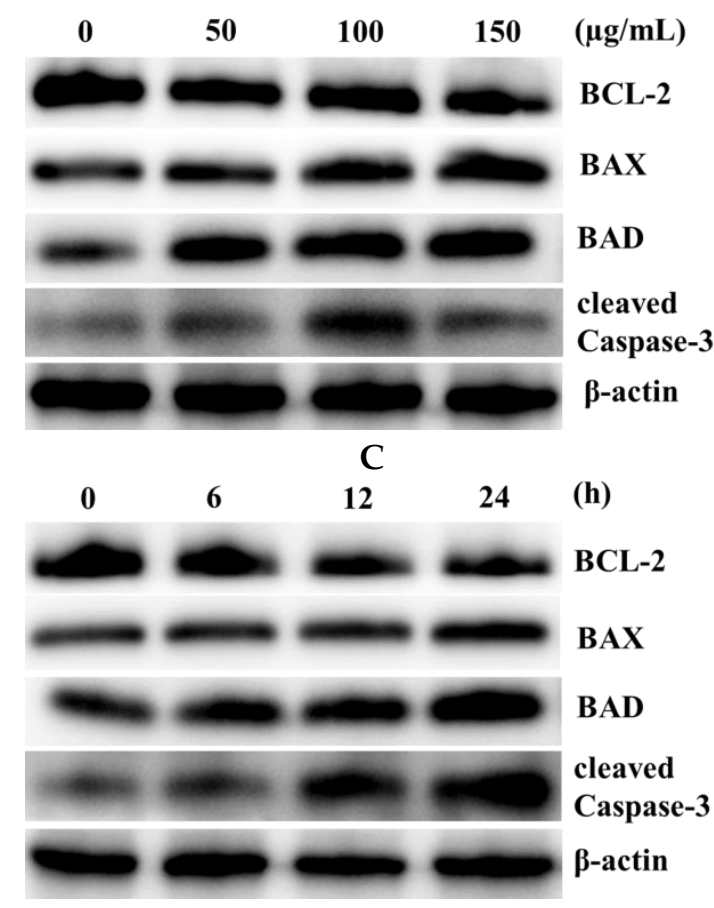

B
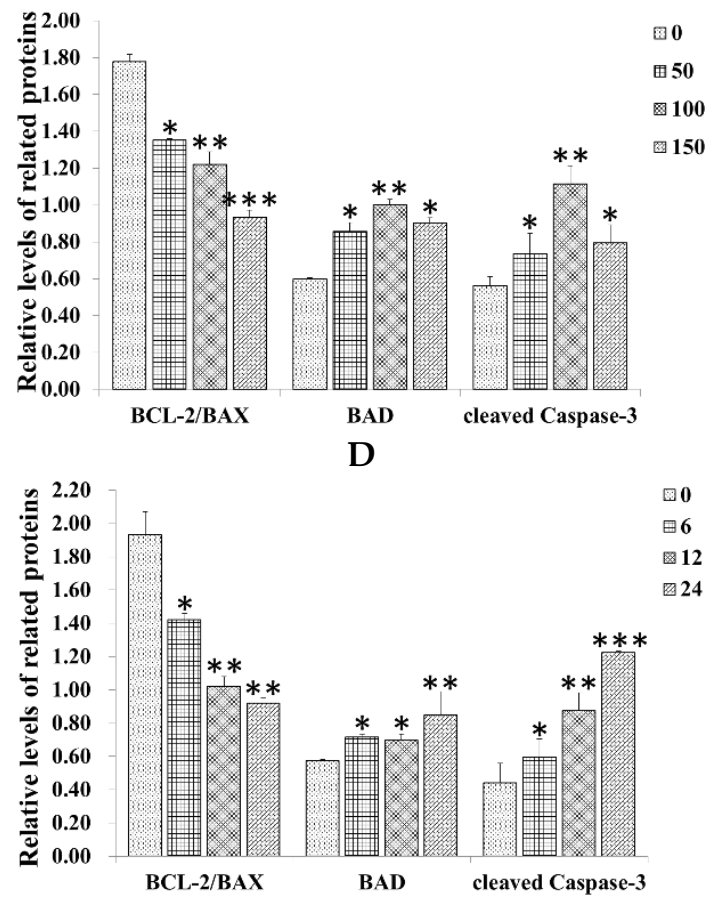

Figure 3. SiNPs induced the expression of the apoptosis-related proteins in RAW 264.7 macrophage cells. (A,B) The expression of B-cell lymphoma 2 (BCL-2), BCL-2-associated X protein (BAX), BCL-2-associated death promoter (BAD), and cleaved Caspase-3 was analyzed via western blot analysis. Cells were exposed to different concentrations of $\operatorname{SiNPs}(0,50,100$, and $150 \mu \mathrm{g} / \mathrm{mL})$ for $12 \mathrm{~h}$. (C,D) Cells were exposed to different times $(0,6,12$, and $24 \mathrm{~h})$ with $100 \mu \mathrm{g} / \mathrm{mL}$ SiNPs. Analyses of the band intensity on the films are presented as the relative ratio of the related proteins to $\beta$-actin. Statistical analysis is shown in the bar graphs. Data are presented as the mean \pm SDM of three independent experiments. Statistically different from the control is marked with asterisks $\left({ }^{*} p<0.05,{ }^{* *} p<0.01\right.$, and $\left.{ }^{* *} p<0.001\right)$.

\subsection{Effect of 4-PBA on SiNP-Induced Apoptosis in RAW 264.7 Macrophage Cells}

To confirm whether ER stress regulates SiNP-induced cell apoptosis, RAW 264.7 macrophage cells were treated with SiNPs in the presence or absence of the ER stress inhibitor 4-PBA. Similar results were observed using the CCK- 8 and flow cytometry assays. The results of CCK- 8 showed that pretreatment with $1 \mathrm{mM}$ 4-PBA for $1 \mathrm{~h}$ significantly promoted cell viability after exposure to 0, 50, 100, and $150 \mu \mathrm{g} / \mathrm{mL}$ SiNPs for $24 \mathrm{~h}$ (Figure $4 \mathrm{~A}$ ). The results of flow cytometry showed that pretreatment with $1 \mathrm{mM}$ 4-PBA significantly inhibited cell apoptosis after exposure to $0,50,100$, and $150 \mu \mathrm{g} / \mathrm{mL}$ SiNPs for $24 \mathrm{~h}$, respectively (Figure 4B,C). Meanwhile, 4-PBA markedly reduced the immunofluorescence staining of GRP78 (green fluorescence, Alexa Fluor ${ }^{\circledR} 488$ ) and CHOP (red fluorescence, Alexa Fluor ${ }^{\circledR}$ 647) after exposure to $100 \mu \mathrm{g} / \mathrm{mL}$ SiNPs for $12 \mathrm{~h}$ in RAW 264.7 macrophage cells (Figure 5A; Supplementary Materials, Figure S2A). In addition, the results of western blot also revealed that the protein levels of GRP78, CHOP, ERO1 $\alpha$, and cleaved Caspase- 3 were significantly decreased in the SiNPs + 4-PBA-exposed RAW 264.7 macrophage cells, while the ratio of BCL-2/BAX was not significantly increased compared with the SiNP exposure group (Figure 5B,C). 
A

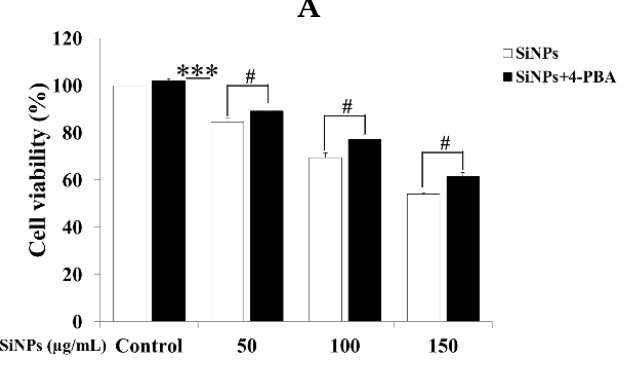

B

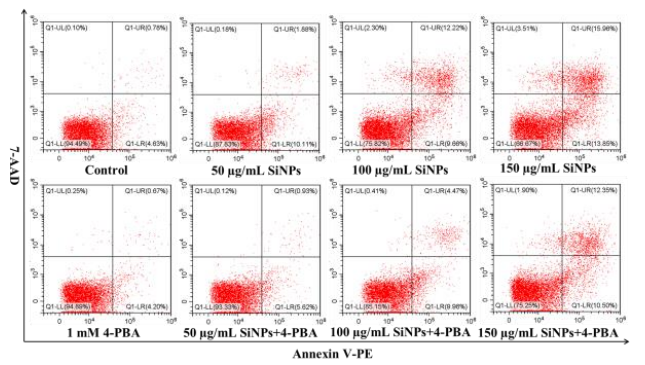

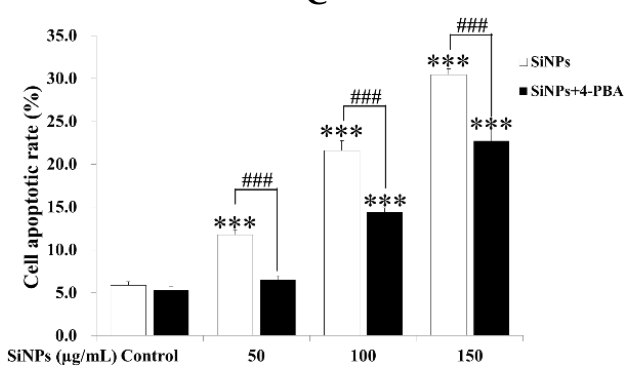

Figure 4. Effect of 4-PBA on cell viability in SiNP-exposed RAW 264.7 macrophage cells. (A) Cell viability was determined for the CCK-8 assay. RAW 264.7 macrophage cells were exposed to 0, 50, 100, and $150 \mu \mathrm{g} / \mathrm{mL}$ SiNPs in the presence or absence of $1 \mathrm{mM} \mathrm{4-PBA}$ for $24 \mathrm{~h}$. (B,C) Cell apoptotic rate was detected via flow cytometry analysis. RAW 264.7 macrophages were pretreated with $1 \mathrm{mM}$ 4-PBA for $1 \mathrm{~h}$, and exposed to 0, 50, 100, and $150 \mu \mathrm{g} / \mathrm{mL}$ SiNPs for $24 \mathrm{~h}$, then collected for Annexin $\mathrm{V}-\mathrm{PE} / 7-\mathrm{AAD}$ staining. UL quadrant is the part of cell death caused by mechanical damage or necrotic cells, UR quadrant is the part of late apoptotic cells, LL quadrant is the part of the normal cells, and LR quadrant is the part of early apoptotic cells. The number of cell apoptosis included the part of LR quadrant (early apoptotic cells) and UR quadrant (late apoptotic cells). The statistical analysis is shown in the bar graph. Data are presented as the mean \pm SDM of three independent experiments. Statistically different from the control is marked with asterisks (*** $p<0.001)$, and statistically different from SiNPs is marked with number sign (\# $p<0.05$ and \#\#\# $p<0.001$ ).

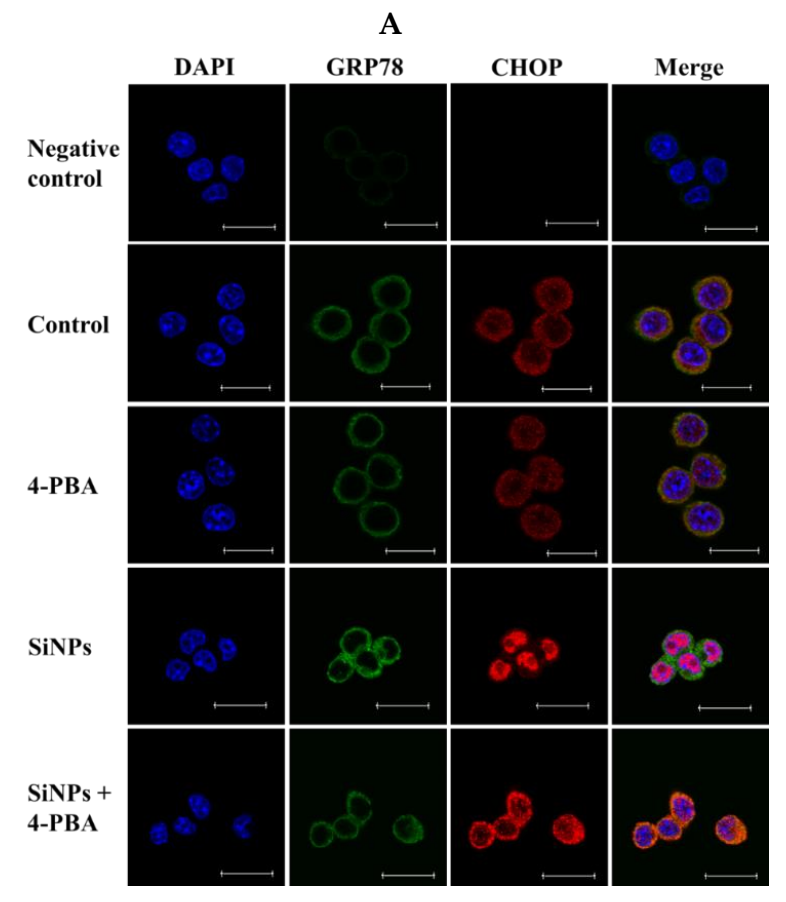

Figure 5. Cont. 

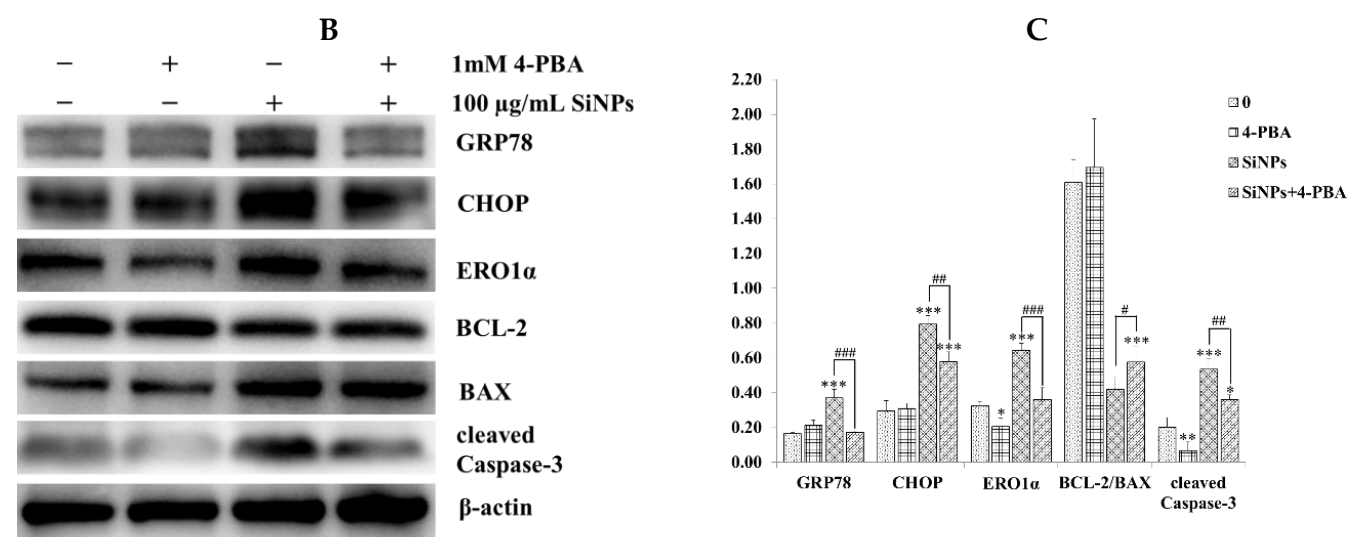

Figure 5. Effect of 4-PBA on the expression of the ER stress- and apoptosis-related proteins in SiNP-exposed RAW 264.7 macrophage cells. (A) Confocal immunofluorescence photomicrography showed the expression of GRP78 (green fluorescence) and CHOP (red fluorescence) in the control (the upper panels), SiNP (the center panels) and SiNP + 4-PBA cells (the bottom panels). RAW 264.7 macrophages were pretreated with $1 \mathrm{mM} 4$-PBA for $1 \mathrm{~h}$, and exposed to $100 \mu \mathrm{g} / \mathrm{mL}$ SiNPs for $12 \mathrm{~h}$. Scale bars, $20 \mu \mathrm{m}$. (B,C) Western blot analysis of GRP78, CHOP, ERO1 $\alpha$, BCL-2, BAX, and cleaved Caspase-3 in SiNP-exposed RAW 264.7 macrophage cells for $12 \mathrm{~h}$. The analyses of the band intensities on films are presented as the relative ratio of target proteins to $\beta$-actin. Statistical analysis is shown in the bar graphs. Data are presented as the mean \pm SDM of three independent experiments. Statistically different from the control is marked with asterisks (* $p<0.05$, ${ }^{* *} p<0.01$, and ${ }^{* * *} p<0.001$ ), and statistically different from SiNPs is marked with number sign (\# $p<0.05$, \#\# $p<0.01$, and \#\#\# $p<0.001$ ).

2.5. Verification of the Overexpression and Knockdown Efficiency of Recombinant CCAAT/Enhancer Binding Protein Homologous (CHOP) Lentivirus Vectors in RAW 264.7 Macrophage Cells

The recombinant lentivirus vectors (Lv)-CHOP and three shCHOPs were successfully constructed. Lentivirus packaging and titration determination were processed in HEK 293T cells. Lv-CHOP, Lv-Control, three shCHOPs, and shNC lentivirus were transduced into RAW 264.7 macrophage cells. The stably expressed cells of CHOP overexpression and knockdown were selected using puromycin (Figure 6A). The transduction efficiency was more than $90 \%$ via flow cytometry assays (Supplementary Materials, Figure S3A,B). The results of western blot showed that the expression of CHOP in the Lv-CHOP group was significantly increased compared with that in the Lv-Control group (Figure 6B,C). Meanwhile, the results of immunofluorescence staining also showed that CHOP was primarily located in the nucleus of RAW 264.7 macrophage cells and the fluorescence intensity of CHOP in the Lv-CHOP group was stronger than that in the Lv-Control group (Figure 6D; Supplementary Materials, Figure S2B). Three shCHOPs lentiviruses markedly downregulated the expression of CHOP compared with that of the shNC group in the tunicamycin $(\mathrm{Tm}, 10 \mu \mathrm{g} / \mathrm{mL})$ and $\mathrm{SiNP}(100 \mu \mathrm{g} / \mathrm{mL})$-exposed RAW 264.7 macrophage cells for $12 \mathrm{~h}$, with shCHOP-1 (50.7\% and 44.7\%, respectively), shCHOP-2 (78\% and 73.5\%, respectively), and shCHOP-3 (76.5\% and 89.1\%, respectively) (Figure 6E-H). 

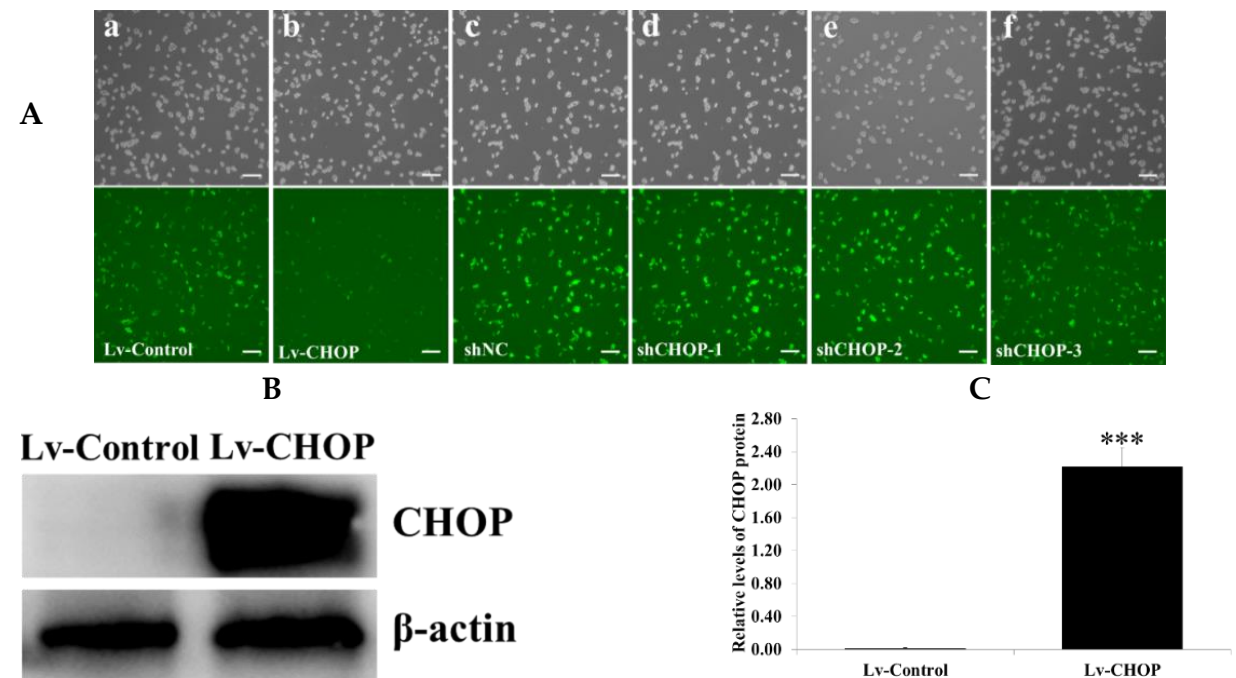

D
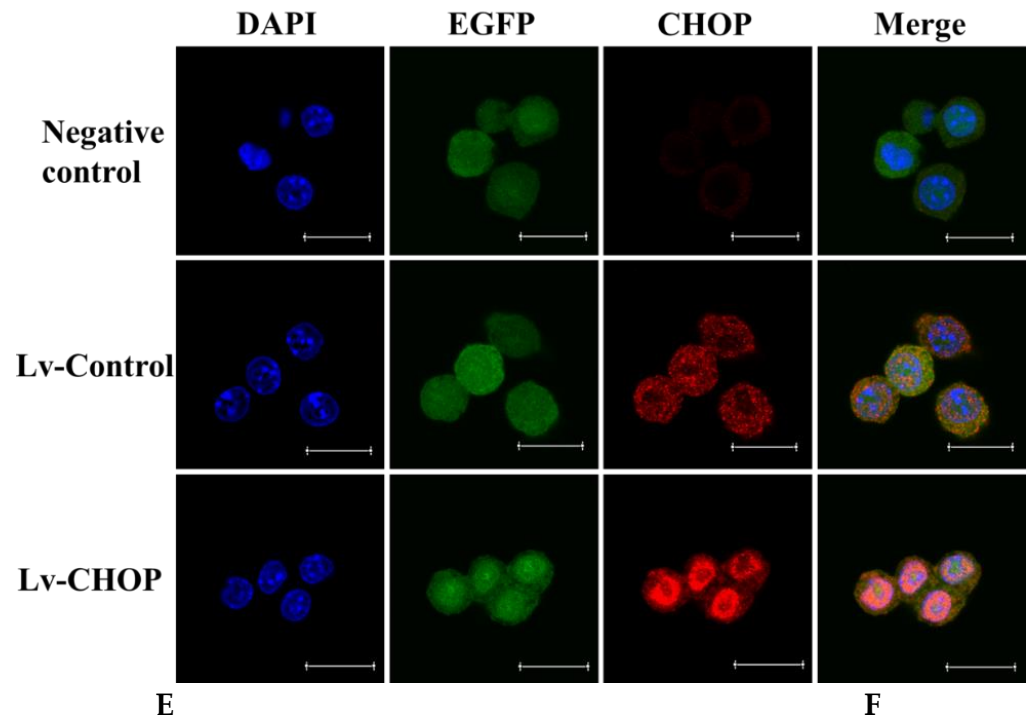

F
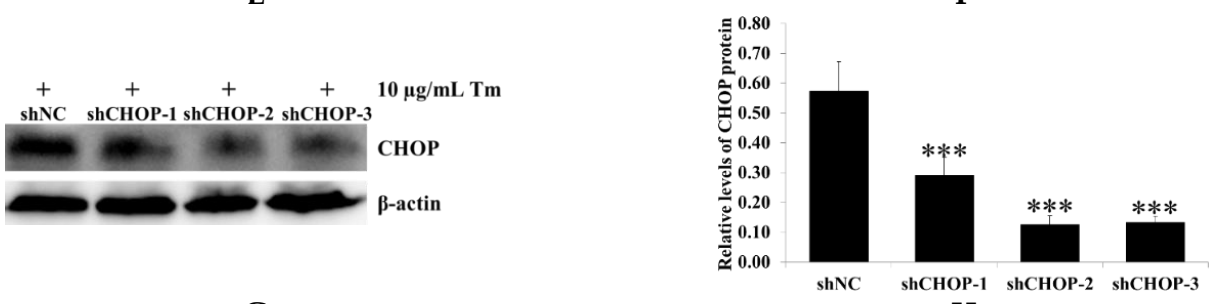

G

$\mathbf{H}$

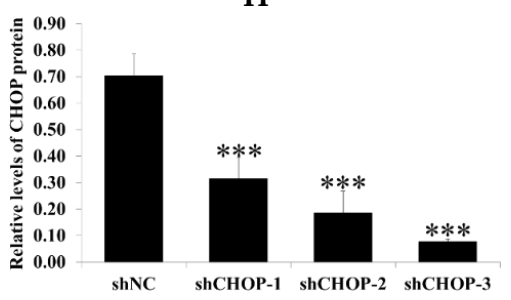

Figure 6. Overexpression and knockdown efficiency of CHOP lentivirus after transduction into RAW 264.7 macrophage cells. RAW 264.7 macrophage cells were transduced with lentivirus vectors (Lv)-CHOP, Lv-Control, three shCHOPs, and shNC lentiviruses, and the stably expressed cells were selected. (A) The plasmids themselves could express enhanced green fluorescent protein (EGFP, green fluorescence), and the proportion of the stably expressed cells expressing EGFP was above $95 \%$ by flow 
cytometry. Fluorescence images of the stably expressed cells of the Lv-CHOP (a), Lv-Control (b), shCHOP-1 (c), shCHOP-2 (d), shCHOP-3 (e), and shNC (f) groups; EGFP expression was observed under light (top panels) or fluorescence microscopy (bottom panels). Scale bars, $100 \mu \mathrm{m}$. (B,C) The expression of CHOP was determined in the stably expressed cells of the Lv-CHOP and Lv-Control groups via western blot analysis. (D) Immunofluorescence analysis of CHOP (red fluorescence) expression and localization in the stably expressed cells of the Lv-CHOP and Lv-Control groups. Scale bars, $20 \mu \mathrm{m}$. (E,F) The expression of CHOP was determined in the stably expressed cells via western blot analysis. The stably expressed cells of shCHOPs were exposed to $10 \mu \mathrm{g} / \mathrm{mL}$ Tm for $12 \mathrm{~h}$ to detect knockdown efficiency. (G,H) The stably expressed cells of shCHOPs were exposed to $100 \mu \mathrm{g} / \mathrm{mL}$ SiNPs for $12 \mathrm{~h}$ to detect knockdown efficiency. The analyses of the band intensity on the films are presented as the relative ratio of CHOP to $\beta$-actin. Statistical analysis is shown in the bar graphs. Data are presented as the mean \pm SDM of three independent experiments. Statistically different from the control is marked with asterisks $\left.{ }^{* * *} p<0.001\right)$.

\subsection{Regulation of CHOP on SiNP-Induced Cell Apoptosis in RAW 264.7 Macrophage Cells}

To determine the role of CHOP on SiNP-induced cell apoptosis, the stable cell lines of CHOP overexpression and knockdown were exposed to $0,50,100$, and $150 \mu \mathrm{g} / \mathrm{mL} \mathrm{SiNPs}$ for $24 \mathrm{~h}$. The results of flow cytometry showed that the apoptotic rate of the Lv-CHOP group $(26.45 \%)$ was higher than that of the Lv-Control group (20.51\%) (Figure 7A,B), while the apoptotic rates of the shCHOP-2 (15.75\%) and shCHOP-3 groups (14.32\%) were lower than that of the shNC group $(20.42 \%)$ (Figure $7 \mathrm{~A}, \mathrm{~B})$. We further detected the role of the shCHOP-3 group in inhibiting apoptosis after exposure to $200 \mu \mathrm{g} / \mathrm{mL}$ SiNPs for $24 \mathrm{~h}$. The results of flow cytometry showed that the apoptotic rates of the shCHOP-3 group $(26.58 \%)$ were lower than that of the shNC group (41.20\%) (Supplementary Materials, Figure S4C,D). Under the condition of no treatment, there is no significant difference between the Lv-Control group (5.47\%) and the Lv-CHOP group (6.19\%), while the apoptotic rates of the shCHOP-3 group (3.81\%) were lower than that of the Lv-CHOP group (6.19\%) (Supplementary Materials, Figure S4A,B).

A

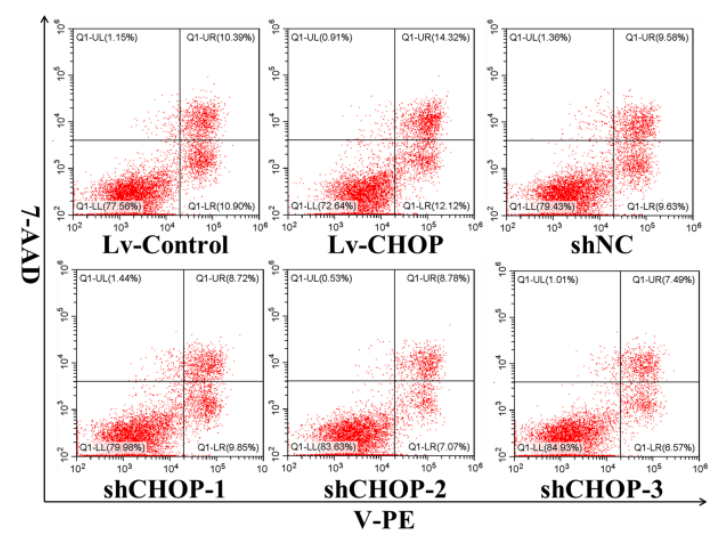

B

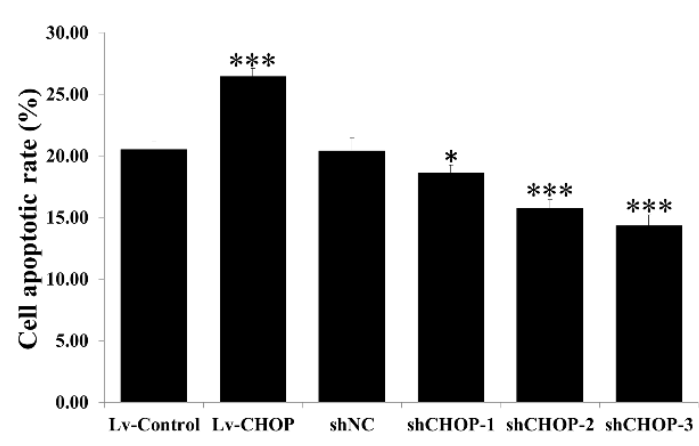

Figure 7. Effect of CHOP on cell apoptosis in RAW 264.7 macrophage cells. (A,B) The stably expressed cells were exposed to $100 \mu \mathrm{g} / \mathrm{mL}$ SiNPs for $24 \mathrm{~h}$. Cells were stained with Annexin V-PE/7-AAD, and the apoptotic rates were determined via flow cytometry analysis. UL quadrant is the part of cell death caused by mechanical damage or necrotic cells, UR quadrant is the part of late apoptotic cells, LL quadrant is the part of the normal cells, and LR quadrant is the part of early apoptotic cells. The number of cell apoptosis included the part of LR quadrant (early apoptotic cells) and UR quadrant (late apoptotic cells). The statistical analysis is shown in the bar graph. Data are presented as the mean \pm SDM of three independent experiments. Statistically different from the control is marked with asterisks (* $p<0.05$ and $\left.{ }^{* * *} p<0.001\right)$. 
2.7. Effect of CHOP Overexpression and Knockdown on the Expression of ER Stress and Apoptosis-Related Proteins in RAW 264.7 Macrophage Cells

To confirm whether $\mathrm{CHOP}$ activated the mitochondrial-mediated apoptotic signaling pathway, we detected the expression of GRP78, ERO1 $\alpha$, BCL-2, BCL-xL, MCL-1, PUMA, BAX, and cleaved Caspase-3. Western blot analysis showed that CHOP overexpression significantly upregulated ERO1 $\alpha$, PUMA, and cleaved Caspase-3, while it downregulated GRP78, BCL-xL, MCL-1, and the ratio of BCL-2/BAX in the Lv-CHOP group (Figure 8A,B; Supplementary Materials, Figure S5A,B). However, CHOP knockdown significantly downregulated ERO1 $\alpha$, PUMA, and cleaved Caspase- 3 in the shCHOP groups, especially the shCHOP-2 and shCHOP-3 groups, and upregulated BCL-xL, MCL-1, and the ratio of $\mathrm{BCL}-2 / \mathrm{BAX}$, while it did not have a significant effect on GRP78 expression in the shCHOP-2 and shCHOP-3 groups (Figure 8A,B; Supplementary Materials, Figure S5A,B).

A

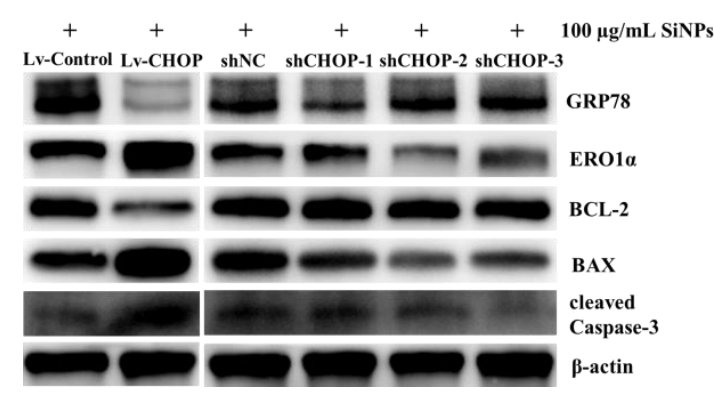

B

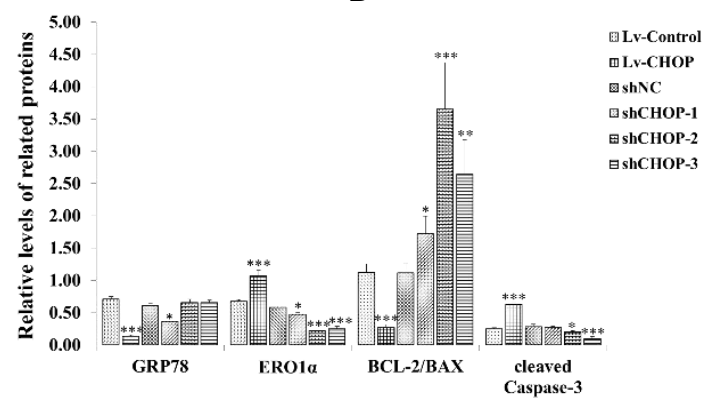

Figure 8. Effect of CHOP on the expression of the ER stress and apoptosis-related proteins in RAW 264.7 macrophage cells. (A,B) The stably expressed RAW 264.7 macrophage cells were exposed to 100 $\mu \mathrm{g} / \mathrm{mL}$ SiNPs for $12 \mathrm{~h}$. The expression of GRP78, CHOP, ERO1 $\alpha$, BCL-2, BAX, and cleaved Caspase-3 were detected via western blot analysis. The analyses of the band intensity on the films are presented as the relative ratio of target proteins to $\beta$-actin, respectively. The statistical analysis is shown in the bar graph. Data are presented as the mean \pm SDM of three independent experiments. Statistically different from the control is marked with asterisks $\left({ }^{*} p<0.05,{ }^{* *} p<0.01\right.$, and $\left.{ }^{* *} p<0.001\right)$.

\section{Discussion}

Previous studies demonstrated that SiNPs caused high toxicity and induced apoptosis in different cell types in vivo and in vitro [29-35]. However, little is known about the detailed molecular mechanisms. In the current study, we demonstrated that SiNPs induced cell apoptosis, at least partly, via ER stress activation in RAW 264.7 macrophage cells, of which the CHOP-mediated apoptotic signaling pathway played an important role in ER stress-induced apoptosis. Consistent with the previous study $[25,36,37]$, our results revealed that SiNPs significantly inhibited cell viability and induced apoptosis in RAW 264.7 macrophage cells. The induction of ER stress by SiNP exposure was evidenced by detection of the ER stress-related proteins, GRP78, CHOP, and ERO1 $\alpha$. 4-PBA, an ER stress inhibitor, could inhibit SiNP-induced GRP78 and CHOP expression in hepatocytes and HPAEpiC [26,27]. Consistent with these studies, our results showed that 4-PBA decreased GRP78, CHOP, and ERO1 $\alpha$ expression, and protected RAW 264.7 macrophage cells from apoptosis induced by SiNP exposure. Furthermore, overexpression of CHOP increased SiNP-induced apoptosis, while knockdown of CHOP decreased SiNP-induced apoptosis. CHOP overexpression enhanced the CHOP-mediated and caspase-dependent mitochondrial-mediated apoptotic signaling pathway by decreasing BCL-xL, MCL-1, and the ratio of BCL-2/BAX and increasing downstream ERO1 $\alpha$, PUMA, and Caspase-3 expression, while CHOP depletion inhibited the apoptotic pathway.

The toxic molecular mechanisms of SiNPs have been studied for decades. One of the mechanisms is that SiNPs produce excessive ROS, which disrupts the balance of $\mathrm{Ca}^{2+}$ in the ER [10,24]. The ER is the major store for cellular $\mathrm{Ca}^{2+}$ and releasing abundant $\mathrm{Ca}^{2+}$ from the ER to the cytoplasm leads to cell death [38]. Depletion of $\mathrm{Ca}^{2+}$ stores in the ER disrupts protein folding, processing, and formation, leading 
to accumulation of unfolded proteins. The disruption of $\mathrm{Ca}^{2+}$ homeostasis and accumulation of unfolded proteins in the ER induces ER stress. ER stress initially attenuates protein translation, promotes protein folding, and activates the misfolded/unfolded protein degradation to restore cellular homeostasis [39]. However, with severe or prolonged ER stress, signaling switches from pro-survival to pro-apoptotic. In the present study, after SiNP exposure, GRP78 and CHOP were significantly augmented in RAW 264.7 macrophage cells. These results are consistent with previous studies that SiNPs could increase the expression of GRP78 and CHOP $[10,25,27,28]$. GRP78 is a typical marker of ER stress activation and induced high expression at the early stage of stress [21]. SiNP exposure increased the expression of GRP78 at the different doses and times, indicating the onset of ER stress in RAW 264.7 macrophage cells after SiNP exposure. CHOP is a key molecule in ER stress-mediated apoptosis, severe and prolonged stress activated CHOP-mediated apoptosis [22]. CHOP upregulation showed that ER stress regulated SiNP-induced apoptosis. Recent studies showed that SiNPs triggered ER stress and then induced apoptosis, of which CHOP increased $[10,25,27,28]$. The present study further confirmed that SiNPs induced apoptosis, at least partly, via activation of the CHOP-mediated signaling pathway.

As a transcription factor, $\mathrm{CHOP}$ does not directly cooperate in cell apoptosis, which interacts with downstream target protein ERO1 $\alpha$ to induce cell apoptosis [40-42]. ERO1 $\alpha$ is an important oxidase and plays an essential role in disulfide bond formation of secreted and cell surface proteins at the posttranslational level $[43,44]$. In addition to its role in normal cellular functions, ERO1 $\alpha$ also cooperates in ER stress-induced apoptosis. As a target of CHOP, the CHOP/ERO1 $\alpha$ pathway underlies hepatocellular apoptosis during acute liver failure (ALF) and ER stress-induced apoptosis in macrophages [41]. In the present study, in addition to GRP78 and CHOP activation, SiNP exposure also increased the expression of $\mathrm{ERO} 1 \alpha$; meanwhile, overexpression and knockdown of $\mathrm{CHOP}$ could regulate ERO1 $\alpha$ expression. CHOP overexpression increased ERO1 $\alpha$ expression and enhanced SiNP-induced apoptosis, while CHOP knockdown decreased ERO1 $\alpha$ expression and inhibited SiNP-induced apoptosis. We speculated that the CHOP-ERO1 $\alpha$ signaling pathway might play an important role in SiNPs-induced apoptosis in RAW 264.7 macrophage cells. Besides the proapoptotic roles, CHOP, in combination with ATF4 and ATF5, might play a pro-survival role in maintaining mitochondrial function through activation of the mitochondrial unfolded protein response (UPRmt) [45,46]. Possibly, CHOP underwent stress-specific post-translational modifications or heterodimerization that dictated their particular function [47]. Whether SiNPs can activate UPRmt, and whether CHOP participated in SiNP-induced UPRmt, will be determined in a future study.

Recent studies have shown that activation of ER stress-mitochondria-mediated apoptotic pathways might cooperate in SiNP-induced endothelial apoptosis [10]. SiNP induced ER stress might regulate the BCL2 family member BCL-2, BCL-xL, MCL-1, PUMA, and BAX, and ultimately upregulate cytochrome c, Caspase- 9 and Caspase-3, leading to the mitochondria-mediated apoptotic caspase cascade $[10,24,48,49]$. Consistent with previous studies, we found that SiNPs significantly increased proapoptotic BAX, BAD, and Caspase-3, while it decreased antiapoptotic BCL-2. Furthermore, we confirmed that SiNP-induced ER stress-associated activation of CHOP could regulate BCL-2, BCL-xL, MCL-1, PUMA, BAX, and Caspase-3. CHOP overexpression increased PUMA, BAX, and Caspase-3 and decreased BCL-2 expression, while CHOP knockdown decreased PUMA, BAX, and Caspase-3 expression. The proapoptotic BCL-2 family members, such as PUMA, BAX, and BCL-2 homologous antagonist killer (BAK), cause mitochondrial membrane disruption [50,51], and BCL-2-associated death promoter (BAD) and BH3 interacting-domain death agonist (BID) inhibit pro-survival BCL-2 and BCL-xL $[52,53]$. ER stress upregulates the expression of proapoptotic BAX and BAD, and activates the caspase cascade [54,55]. We speculated that the CHOP-ERO1 $\alpha$-caspase-dependent apoptotic signaling pathway, at least partly, cooperated in SiNP-induced apoptosis in RAW 264.7 macrophage cells. 


\section{Materials and Methods}

\subsection{Reagents}

Silica nanoparticles (SiNPs, 637246) were purchased from Sigma-Aldrich (St. Louis, MO, USA). Dulbecco's modified Eagle's medium (DMEM), fetal bovine serum (FBS), and Turbofect transfection reagent were purchased from Thermo Fisher Scientific (Waltham, MA, USA). Annexin V-PE/7-AAD kit, total protein extraction kit, and BCA protein assay kit were purchased from Nanjing Keygen Biotech Co., Ltd. (Nanjing, Jiangsu, China). DAPI (4', 6-diamidino-2-phenylindole) was purchased from Beyotime Institute of Biotechnology (Shanghai, China). Anti-GRP78 antibody (C50B12), anti-cleaved Caspase-3 antibody (9664), and anti-mouse and anti-rabbit HRP-linked secondary antibodies (7076P2, 7074P2) were purchased from Cell Signaling Technology (Danvers, MA, USA). Anti-ERO1 $\alpha$ antibody (H00030001-M01) was purchased from Abnova (Taipei, Taiwan). Anti-BCL-2 antibody (ab182858), anti-BCL-xL antibody (ab32370), anti-MCL-1 antibody (ab32087), anti-PUMA antibody (ab33906), anti-BAX antibody (ab32503), anti-BAD antibody (ab32445), and anti-mouse and anti-rabbit fluorescent secondary antibodies (ab150077, ab150115) were purchased from Abcam Ltd. (Cambridge, MA, USA). Anti-CHOP antibody (sc-7351) was purchased from Santa Cruz Biotechnology Inc. (Dallas, TX, USA). Anti- $\beta$-actin antibody (KM9001T) was purchased from Tianjin Sungene Biotechnology Inc. (Tianjin, China).

\subsection{Characterization of SiNPs}

The powder of SiNPs was dispersed in sterilized water (final concentration: $4 \mathrm{mg} / \mathrm{mL}$ ) and stored at $4{ }^{\circ} \mathrm{C}$ until use. The morphology and average size of SiNPs were determined by a transmission electron microscope (TEM; Tecnai 12; Royal Philips, Amsterdam, Holland) using dropping aliquots of SiNP solutions on 400-mesh carbon-coated copper grids (SPI Supplies, West Chester, PA, USA). The zeta potential of SiNPs were examined by a Zetasizer 3000HS (Malvern Instruments Ltd., Malvern, UK). Before experiment use, SiNPs in the stock suspension were dispersed using a sonicator (160 W, 20 kHz, 30 min; Bioruptor UCD-200, Belgium).

\subsection{Cell Line Culture and Treatment}

The RAW 264 murine macrophage cell line was cultured in DMEM containing 10\% FBS and 1\% antibiotic-antimycotic solution in a humidified atmosphere of $5 \% \mathrm{CO}_{2}$ in air at $37^{\circ} \mathrm{C}$. The cells were passaged every $2-3$ days using $0.25 \%$ Tyrisin for $1 \mathrm{~min}$ at room temperature. When cells reached $70-80 \%$ confluence in a plate, they were treated, collected, and processed for further experiments. Firstly, RAW 264.7 macrophages were exposed to various concentrations (0-200 $\mu \mathrm{g} / \mathrm{mL})$ of SiNPs. At various times (0-24 h) during the treatment, cells were collected and processed for CCK-8, flow cytometry, and western blotting detection. Secondly, RAW 264.7 macrophages were exposed to 0, 50, 100, and $150 \mu \mathrm{g} / \mathrm{mL}$ of SiNPs in the presence or absence of $1 \mathrm{mM} 4$-phenylbutyrate (4-PBA), an ER stress inhibitor. After exposure for 0-24 h, the cells were collected and processed for CCK-8, flow cytometry (CytoFLEX S, Beckman Coulter, Inc., Brea, CA, USA), and western blotting detection.

\subsection{Measurement of Cell Viability}

The effects of SiNPs on cell viability were determined by a CCK-8 assay (C6005, New Cell and Molecular Biotech Co. Ltd., Suzhou, Jiangsu, China). RAW 264 macrophage cells were seeded into a 96-well plate at a density of $1 \times 10^{4}$ cells/200 $\mu \mathrm{L}$ medium/well and incubated for $24 \mathrm{~h}$ for attachment. Cells were then replaced with medium containing 0-200 $\mu \mathrm{g} / \mathrm{mL}$ SiNPs and subsequently incubated for 12 and $24 \mathrm{~h}$. Next, the CCK-8 solution was then added, and incubated at $37^{\circ} \mathrm{C}$ for $2 \mathrm{~h}$. The absorbance at $450 \mathrm{~nm}$ was measured at intervals of $1 \mathrm{~h}$ with an ELISA plate reader using a microplate reader (Model 680, Bio-Rad, Hercules, CA, USA). 


\subsection{Cell Apoptosis Assay}

RAW 264 macrophage cells were cultured into $60 \mathrm{~mm}$ dishes at a density of $5 \times 10^{5}$ cells/dish for 12 and $24 \mathrm{~h}$. The cells were then exposed to $0,50,100$, and $150 \mu \mathrm{g} / \mathrm{mL}$ SiNPs and subsequently incubated for 12 and $24 \mathrm{~h}$. Next, the cells were collected and quantified with an Annexin V-PE and 7-AAD apoptosis detection kit. Following the manufacturer's instructions, the cells were trypsinized and collected via centrifugation at $2000 \mathrm{rpm}$ for $5 \mathrm{~min}$. The cells were resuspended in $50 \mu \mathrm{L}$ binding buffer supplemented with $5 \mu \mathrm{L}$ 7-AAD for $10 \mathrm{~min}$ at room temperature in the dark. Then, $450 \mu \mathrm{L}$ binding buffer was added, followed by the addition of $1 \mu \mathrm{L}$ Annexin V-PE for another $10 \mathrm{~min}$. Apoptosis was detected using flow cytometry (CytoFLEX S, Beckman Coulter, Inc., Brea, CA, USA) within $1 \mathrm{~h}$.

\subsection{Immunofluorescence Staining}

RAW 264 macrophage cells were cultured on sterile cover slips placed in 24-well culture plates. The cells were then exposed to $100 \mu \mathrm{g} / \mathrm{mL}$ SiNPs, in the presence or absence of $1 \mathrm{mM} 4-\mathrm{PBA}$, and subsequently incubated for $12 \mathrm{~h}$. The cells were then fixed in paraformaldehyde (PFA) solution (4\%, $v / v)$ overnight at $4{ }^{\circ} \mathrm{C}$. Following fixation, the cells were permeabilized with $0.5 \%$ TritonX-100 for 10 min, blocked with 5\% BSA for $1 \mathrm{~h}$, and then exposed to anti-CHOP and anti-GRP78 antibodies (1:250 dilutions) overnight at $4{ }^{\circ} \mathrm{C}$. After washing, the cells were incubated with anti-mouse and anti-rabbit fluorescent secondary antibodies (1:1000 dilutions) at $37^{\circ} \mathrm{C}$ for $1 \mathrm{~h}$ in the dark and DAPI for $10 \mathrm{~min}$ at room temperature. Finally, the cells were examined under a laser scanning confocal microscope (TCS SP8 STED; Wetzlar, Hessen, GER). Fluorescence intensity of the images was analyzed with Leica Application Suite X System (Leica, Wetzlar, Hessen, GER).

\subsection{Construction of Recombinant CHOP Overexpression and Short Hairpin Interfering RNA (shRNA) Lentivirus Plasmid and Cell Transduction}

Primers were designed to amplify the CDS sequence of CHOP and cloned into pCD513B-1 plasmids (SBI, Mountain View, CA, USA) to construct a CHOP overexpression lentiviral vector ( $\mathrm{Lv}-\mathrm{CHOP}$ ), and pCD513B-1 was used as a negative control group (Lv-Control). Three short hairpin interfering RNA (shRNAs) sequences of CHOP and one negative control sequence were designed and cloned into pCD513B-U6 plasmids to construct CHOP shRNA lentiviral vectors (shCHOP-1, shCHOP-2, and shCHOP-3) and a negative control shRNA vector (shNC). pCD513B-U6 plasmids were reconstructed at the basis of pCD513B-1 [56]. CHOP lentiviral vectors were transfected into HEK 293T cells with three expression vectors encoding the packaging proteins Gag-Pol, Rev, Tat, and the G-protein of the vesicular stomatitis virus (VSVG) using Turbofect transfection reagent, respectively. After transfection for $72 \mathrm{~h}$, the lentivirus-containing supernatants were harvested, purified by low-speed centrifugation, filtered through a $0.45 \mu \mathrm{m}$ polyvinylidene difluoride (PVDF) filter, and the lentivirus was concentrated using PEG 8000 and stored at $-80^{\circ} \mathrm{C}$ until use. Lentivirus titer was determined by serial dilution $\left(10^{0}-10^{7}\right)$. RAW 264.7 macrophages were cultured into $60 \mathrm{~mm}$ plates at a density of $1 \times 10^{5}$ cells/well. After $24 \mathrm{~h}$, the cells were transduced with an appropriate number of lentiviral particles (multiplicity of infection (MOI) was about 20) in DMEM supplemented with $10 \% \mathrm{FBS}$ and $8 \mu \mathrm{g} / \mathrm{mL}$ polybrene (Sigma Aldrich, St. Louis, $\mathrm{MO}, \mathrm{USA}$ ). After transduction for $12 \mathrm{~h}$, the lentivirus-containing medium was removed and replaced with fresh DMEM. Following an additional $48 \mathrm{~h}$, the stably expressed cells of CHOP overexpression and shRNAs were selected using puromycin (10 $\mu \mathrm{g} / \mathrm{mL}$, Sigma Aldrich, St. Louis, MO, USA).

\subsection{Western Blotting}

Proteins were extracted from RAW 264 macrophage cells using lysis buffer (Nanjing KeyGen Biotech, Nanjing, China). Protein quantification was measured with a bicinchoninic acid (BCA) protein assay kit (Nanjing KeyGen Biotech, Nanjing, China). Equal amounts of protein $(20 \mu \mathrm{g})$ were separated by $10 \%$ sodium dodecyl sulfate-polyacrylamide gel electrophoresis (SDS-PAGE) and electrotransferred to 0.22- $\mu \mathrm{m}$ PVDF membranes (Millipore, Bedford, MA, USA). Following transfer, membranes were blocked 
in TBST supplemented with $10 \%$ skim milk for $1 \mathrm{~h}$ at room temperature and incubated overnight at $4{ }^{\circ} \mathrm{C}$ with the relevant primary antibodies. After $12 \mathrm{~h}$, the membranes were incubated with the appropriate HRP-labeled secondary antibodies (1:5000 dilutions) for $1 \mathrm{~h}$ at room temperature. Immunoreactive bands were visualized using enhanced chemiluminescence (ECL) reagent (New Cell and Molecular Biotech Co. Ltd., Suzhou, Jiangsu, China) under a Gel Imaging System (Tannon Science and Technology, Shanghai, China), and protein levels were digitized with the Quantity One software (Bio-Rad, Hercules, CA, USA).

\subsection{Statistical Analysis}

Data from the present study are presented as mean \pm SDM from at least triplicate independent experiments. Data were analyzed with one-way analysis of variance (ANOVA), followed by Fisher's least significant different test (Fisher LSD) and an independent samples $t$-test with the Statistical Package for the Social Sciences (SPSS) software (Version 18.0; SPSS, Chicago, IL, USA). The critical value for statistical significance was $p<0.05$.

\section{Conclusions}

In summary, our results showed that SiNP exposure reduced cell viability and induced cell apoptosis in RAW 264.7 macrophage cells in dose- and time-dependent manners. In parallel, SiNPs induced ER stress by increasing the levels of GRP78, CHOP, and ERO1 $\alpha$ expression in RAW 264.7 macrophage cells. The 4-PBA attenuated SiNP-induced ER stress, and inhibited SiNP-induced apoptosis. Overexpression of CHOP increased SiNP-induced apoptosis, while knockdown of CHOP decreased SiNP-induced apoptosis. Regarding the mechanisms, CHOP enhanced the CHOP-mediated and caspase-dependent apoptotic signaling pathways by decreasing the ratio of BCL-2/BAX, BCL-xL, and MCL-1, and increasing downstream ERO1 $\alpha$, PUMA, and Caspase-3 expression. Taken together, we speculated that SiNPs induced ER stress and promoted cell apoptosis, at least partly, via the CHOP-ERO1 $\alpha$-caspase apoptotic signaling pathway. Our findings may provide an in vitro evidence for the potential toxicity of SiNPs, and also offer essential information for a further understanding of toxic mechanisms of SiNPs.

Supplementary Materials: Supplementary Materials can be found at http://www.mdpi.com/1422-0067/20/23/ 5846/s1.

Author Contributions: Conceptualization, F.C.; methodology, F.C., J.J., J.H. and Y.W.; software, F.C., J.J. and J.H.; validation, F.C., J.J., J.H., Y.W., Z.M. and J.Z.; resources, F.C.; data curation, F.C., J.J., J.H. and Y.W.; writing-original draft preparation, J.J.; writing —review and editing, F.C., Z.M. and J.Z.; supervision, F.C.; project administration, F.C.; funding acquisition, F.C.

Funding: This research was funded by the National Natural Science Foundation of China (grant number: 31702298), the Natural Science Foundation of Jiangsu Province (grant number: BK20170498), China Postdoctoral Science Foundation (grant number: 2017M621843), the Natural Science Foundation of Jiangsu Higher Education Institutions of China (grant number: 17KJD230002), the Priority Academic Program Development of Jiangsu Higher Education Institution (PAPD).

Conflicts of Interest: The authors declare no conflict of interest.

\section{Abbreviations}

$\begin{array}{ll}\text { SiNPs } & \text { Silica nanoparticles } \\ \text { ER } & \text { Endoplasmic reticulum } \\ \text { NPs } & \text { Nanoparticles } \\ \text { OECD } & \text { Organization for Economic Cooperation and Development } \\ \text { ROS } & \text { Reactive oxygen species } \\ \text { GRP78 } & \text { Glucose-regulated protein } 78 \\ \text { CHOP } & \text { CCAAT/enhancer binding protein homologous protein } \\ \text { ERO1 } \alpha & \text { ER oxidoreduclin } 1 \alpha \\ \text { PI } & \text { Propidium iodide } \\ \text { PVDF } & \text { Polyvinylidene difluoride }\end{array}$




$\begin{array}{ll}\text { MOI } & \text { Multiplicity of infection } \\ \text { ECL } & \text { Enhanced chemiluminescence } \\ \text { BCL-2 } & \text { B-cell lymphoma } 2 \\ \text { BAD } & \text { BCL-2-associated death promoter } \\ \text { BAX } & \text { BCL-2-associated X protein } \\ \text { Tm } & \text { Tunicamycin } \\ \text { UPRmt } & \text { Mitochondrial unfolded protein response }\end{array}$

\section{References}

1. Brumfiel, G. Nanotechnology: A little knowledge. Nature 2003, 424, 246-248. [CrossRef] [PubMed]

2. Service, R.F. Nanotoxicology: Nanotechnology grows up. Science 2004, 304, 1732-1734. [CrossRef] [PubMed]

3. Yang, Y.; Li, J. Lipid, protein and poly(NIPAM) coated mesoporous silica nanoparticles for biomedical applications. Adv. Colloid Interface Sci. 2014, 207, 155-163. [CrossRef] [PubMed]

4. Mai, W.X.; Meng, H. Mesoporous silica nanoparticles: A multifunctional nano therapeutic system. Integr. Biol. 2013, 5, 19-28. [CrossRef] [PubMed]

5. Xu, R.; Zhang, G.; Mai, J.; Deng, X.; Segura-Ibarra, V.; Wu, S.; Shen, J.; Liu, H.; Hu, Z.; Chen, L.; et al. An injectable nanoparticle generator enhances delivery of cancer therapeutics. Nat. Biotechnol. 2016, 34, 414-418. [CrossRef]

6. Zhang, Y.; Hu, H.; Shi, Y.; Yang, X.; Cao, L.; Wu, J.; Asweto, C.O.; Feng, L.; Duan, J.; Sun, Z. (1)H NMR-based metabolomics study on repeat dose toxicity of fine particulate matter in rats after intratracheal instillation. Sci. Total Environ. 2017, 589, 212-221. [CrossRef]

7. Oberdorster, G.; Oberdorster, E.; Oberdorster, J. Nanotoxicology: An emerging discipline evolving from studies of ultrafine particles. Environ. Health Perspect. 2005, 113, 823-839. [CrossRef]

8. Du, Z.; Zhao, D.; Jing, L.; Cui, G.; Jin, M.; Li, Y.; Liu, X.; Liu, Y.; Du, H.; Guo, C.; et al. Cardiovascular toxicity of different sizes amorphous silica nanoparticles in rats after intratracheal instillation. Cardiovasc. Toxicol. 2013, 13, 194-207. [CrossRef]

9. Matsuo, K.; Hirobe, S.; Okada, N.; Nakagawa, S. Analysis of Skin Permeability and Toxicological Properties of Amorphous Silica Particles. Biol. Pharm. Bull. 2016, 39, 1201-1205. [CrossRef]

10. Guo, C.X.; Ma, R.; Liu, X.Y.; Xia, Y.Y.; Niu, P.Y.; Ma, J.X.; Zhou, X.Q.; Li, Y.B.; Sun, Z.W. Silica nanoparticles induced endothelial apoptosis via endoplasmic reticulum stress-mitochondrial apoptotic signaling pathway. Chemosphere 2018, 210, 183-192. [CrossRef]

11. Liang, H.; Jin, C.; Tang, Y.; Wang, F.D.; Ma, C.W.; Yang, Y.J. Cytotoxicity of silica nanoparticles on HaCaT cells. J. Appl. Toxicol. 2014, 34, 367-372. [CrossRef] [PubMed]

12. Lin, W.S.; Huang, Y.W.; Zhou, X.D.; Ma, Y.F. In vitro toxicity of silica nanoparticles in human lung cancer cells. Toxicol. Appl. Pharm. 2006, 217, 252-259. [CrossRef] [PubMed]

13. Park, E.J.; Park, K. Oxidative stress and pro-inflammatory responses induced by silica nanoparticles in vivo and in vitro. Toxicol. Lett. 2009, 184, 18-25. [CrossRef] [PubMed]

14. Eom, H.J.; Choi, J. Oxidative stress of silica nanoparticles in human bronchial epithelial cell, Beas-2B. Toxicol. Vitr. 2009, 23, 1326-1332. [CrossRef] [PubMed]

15. Ye, Y.; Liu, J.; Chen, M.; Sun, L.; Lan, M. In vitro toxicity of silica nanoparticles in myocardial cells. Environ. Toxicol. Pharm. 2010, 29, 131-137. [CrossRef]

16. Eom, H.J.; Choi, J. SiO(2) Nanoparticles Induced Cytotoxicity by Oxidative Stress in Human Bronchial Epithelial Cell, Beas-2B. Environ. Health Toxicol. 2011, 26, e2011013. [CrossRef]

17. Passagne, I.; Morille, M.; Rousset, M.; Pujalte, I.; L'Azou, B. Implication of oxidative stress in size-dependent toxicity of silica nanoparticles in kidney cells. Toxicology 2012, 299, 112-124. [CrossRef]

18. Sun, L.; Li, Y.; Liu, X.M.; Jin, M.H.; Zhang, L.; Du, Z.J.; Guo, C.X.; Huang, P.L.; Sun, Z.W. Cytotoxicity and mitochondrial damage caused by silica nanoparticles. Toxicol. Vitr. 2011, 25, 1619-1629. [CrossRef]

19. Ahmad, J.; Ahamed, M.; Akhtar, M.J.; Alrokayan, S.A.; Siddiqui, M.A.; Musarrat, J.; Al-Khedhairy, A.A. Apoptosis induction by silica nanoparticles mediated through reactive oxygen species in human liver cell line HepG2. Toxicol. Appl. Pharm. 2012, 259, 160-168. [CrossRef]

20. Yu, Y.B.; Duan, J.C.; Yu, Y.; Li, Y.; Liu, X.M.; Zhou, X.Q.; Huang, P.L.; Sun, Z.W. Amorphous silica nanoparticles induce autophagic cell death in HepG2 cells triggered by reactive oxygen species. Toxicol. Lett. 2013, 221, S239. [CrossRef] 
21. Rao, R.V.; Peel, A.; Logvinova, A.; del Rio, G.; Hermel, E.; Yokota, T.; Goldsmith, P.C.; Ellerby, L.M.; Ellerby, H.M.; Bredesen, D.E. Coupling endoplasmic reticulum stress to the cell death program: Role of the ER chaperone GRP78. FEBS Lett. 2002, 514, 122-128. [CrossRef]

22. Oyadomari, S.; Mori, M. Roles of CHOP/GADD153 in endoplasmic reticulum stress. Cell Death Differ. 2004, 11, 381-389. [CrossRef] [PubMed]

23. Christen, V.; Fent, K. Silica nanoparticles and silver-doped silica nanoparticles induce endoplasmatic reticulum stress response and alter cytochrome P4501A activity. Chemosphere 2012, 87, 423-434. [CrossRef] [PubMed]

24. Yang, Y.Y.; Yu, Y.B.; Wang, J.H.; Li, Y.B.; Li, Y.; Wei, J.; Zheng, T.; Jin, M.H.; Sun, Z.W. Silica nanoparticles induced intrinsic apoptosis in neuroblastoma SH-SY5Y cells via CytC/Apaf-1 pathway. Environ. Toxicol. Pharmacol. 2017, 52, 161-169. [CrossRef] [PubMed]

25. Guo, C.X.; Ma, R.; Liu, X.Y.; Chen, T.; Li, Y.; Yu, Y.; Duan, J.C.; Zhou, X.Q.; Li, Y.B.; Sun, Z.W. Silica nanoparticles promote oxLDL-induced macrophage lipid accumulation and apoptosis via endoplasmic reticulum stress signaling. Sci. Total Environ. 2018, 631-632, 570-579. [CrossRef] [PubMed]

26. Wang, J.; Li, Y.; Duan, J.; Yang, M.; Yu, Y.; Feng, L.; Yang, X.; Zhou, X.; Zhao, Z.; Sun, Z. Silica nanoparticles induce autophagosome accumulation via activation of the EIF2AK3 and ATF6 UPR pathways in hepatocytes. Autophagy 2018, 14, 1185-1200. [CrossRef]

27. Wu, T.S.; Zhang, S.H.; Liang, X.; He, K.Y.; Wei, T.T.; Wang, Y.; Zou, L.Y.; Zhang, T.; Xue, Y.Y.; Tang, M. The apoptosis induced by silica nanoparticle through endoplasmic reticulum stress response in human pulmonary alveolar epithelial cells. Toxicol. Vitr. 2019, 56, 126-132. [CrossRef]

28. Lee, K.; Lee, J.; Kwak, M.; Cho, Y.L.; Hwang, B.; Cho, M.J.; Lee, N.G.; Park, J.; Lee, S.H.; Park, J.G.; et al. Two distinct cellular pathways leading to endothelial cell cytotoxicity by silica nanoparticle size. J. Nanobiotechnol. 2019, 17, 24. [CrossRef]

29. Yang, X.; Feng, L.; Zhang, Y.; Hu, H.; Shi, Y.; Liang, S.; Zhao, T.; Cao, L.; Duan, J.; Sun, Z. Co-exposure of silica nanoparticles and methylmercury induced cardiac toxicity in vitro and in vivo. Sci. Total Environ. 2018, 631-632, 811-821. [CrossRef]

30. Liu, J.; Yang, M.; Jing, L.; Ren, L.; Wei, J.; Zhang, J.; Zhang, F.; Duan, J.; Zhou, X.; Sun, Z. Silica nanoparticle exposure inducing granulosa cell apoptosis and follicular atresia in female Balb/c mice. Environ. Sci. Pollut. Res. Int. 2018, 25, 3423-3434. [CrossRef]

31. Han, J.W.; Jeong, J.K.; Gurunathan, S.; Choi, Y.J.; Das, J.; Kwon, D.N.; Cho, S.G.; Park, C.; Seo, H.G.; Park, J.K.; et al. Male- and female-derived somatic and germ cell-specific toxicity of silver nanoparticles in mouse. Nanotoxicology 2016, 10, 361-373. [CrossRef] [PubMed]

32. Hirai, T.; Yoshioka, Y.; Takahashi, H.; Ichihashi, K.; Udaka, A.; Mori, T.; Nishijima, N.; Yoshida, T.; Nagano, K.; Kamada, H.; et al. Cutaneous exposure to agglomerates of silica nanoparticles and allergen results in IgE-biased immune response and increased sensitivity to anaphylaxis in mice. Part. Fibre Toxicol. 2015, 12, 16. [CrossRef] [PubMed]

33. Higashisaka, K.; Kunieda, A.; Iwahara, Y.; Tanaka, K.; Tsunoda, S.; Yoshioka, Y.; Tsutsumi, Y. The contribution of silica nanoparticles-induced neutrophilia to pregnancy complications in mice. Toxicol. Lett. 2014, 229, S193. [CrossRef]

34. Li, J.; He, X.; Yang, Y.; Li, M.; Xu, C.; Yu, R. Risk assessment of silica nanoparticles on liver injury in metabolic syndrome mice induced by fructose. Sci. Total Environ. 2018, 628-629, 366-374. [CrossRef] [PubMed]

35. Yagi, K.; Nishimori, H.; Kondoh, M.; Isoda, K.; Tsunoda, S.; Tsutsumi, Y. Hepatotoxicity of silica nanoparticles in mice. Toxicol. Lett. 2009, 189, S184. [CrossRef]

36. Marquardt, C.; Fritsch-Decker, S.; Al-Rawi, M.; Diabate, S.; Weiss, C. Autophagy induced by silica nanoparticles protects RAW264.7 macrophages from cell death. Toxicology 2017, 379, 40-47. [CrossRef]

37. Xi, C.; Wang, Z.; Zhou, J.; Shen, F.; Huang, Z. Activation of autophagy protects against mesoporous silica nanoparticles-induced NF-kappa B dependent inflammation in macrophagy. Toxicol. Lett. 2016, 258, S266-S267. [CrossRef]

38. Paschen, W.; Doutheil, J. Disturbances of the functioning of endoplasmic reticulum: A key mechanism underlying neuronal cell injury? J. Cereb. Blood Flow Metab. Off. J. Int. Soc. Cereb. Blood Flow Metab. 1999, 19, 1-18. [CrossRef] 
39. Nakka, V.P.; Prakash-babu, P.; Vemuganti, R. Crosstalk Between Endoplasmic Reticulum Stress, Oxidative Stress, and Autophagy: Potential Therapeutic Targets for Acute CNS Injuries. Mol. Neurobiol. 2016, 53, 532-544. [CrossRef]

40. Li, G.; Mongillo, M.; Chin, K.T.; Harding, H.; Ron, D.; Marks, A.R.; Tabas, I. Role of ERO1-alpha-mediated stimulation of inositol 1,4,5-triphosphate receptor activity in endoplasmic reticulum stress-induced apoptosis. J. Cell Biol. 2009, 186, 783-792. [CrossRef]

41. Rao, J.; Zhang, C.; Wang, P.; Lu, L.; Qian, X.; Qin, J.; Pan, X.; Li, G.; Wang, X.; Zhang, F. C/EBP homologous protein (CHOP) contributes to hepatocyte death via the promotion of ERO1alpha signalling in acute liver failure. Biochem. J. 2015, 466, 369-378. [CrossRef] [PubMed]

42. Marciniak, S.J.; Yun, C.Y.; Oyadomari, S.; Novoa, I.; Zhang, Y.H.; Jungreis, R.; Nagata, K.; Harding, H.P.; Ron, D. CHOP induces death by promoting protein synthesis and oxidation in the stressed endoplasmic reticulum. Genes Dev. 2004, 18, 3066-3077. [CrossRef] [PubMed]

43. Fan, F.; Zhang, Y.; Huang, G.; Zhang, Q.; Wang, C.C.; Wang, L.; Lu, D. AtERO1 and AtERO2 Exhibit Differences in Catalyzing Oxidative Protein Folding in the Endoplasmic Reticulum. Plant Physiol. 2019, 180, 2022-2033. [CrossRef] [PubMed]

44. Zhang, L.; Niu, Y.; Zhu, L.; Fang, J.; Wang, X.; Wang, L.; Wang, C.C. Different interaction modes for protein-disulfide isomerase (PDI) as an efficient regulator and a specific substrate of endoplasmic reticulum oxidoreductin-1alpha (Ero1alpha). J. Biol. Chem. 2014, 289, 31188-31199. [CrossRef] [PubMed]

45. Quiros, P.M.; Prado, M.A.; Zamboni, N.; D’Amico, D.; Williams, R.W.; Finley, D.; Gygi, S.P.; Auwerx, J. Multi-omics analysis identifies ATF4 as a key regulator of the mitochondrial stress response in mammals. J. Cell Biol. 2017, 216, 2027-2045. [CrossRef]

46. Fiorese, C.J.; Schulz, A.M.; Lin, Y.F.; Rosin, N.; Pellegrino, M.W.; Haynes, C.M. The Transcription Factor ATF5 Mediates a Mammalian Mitochondrial UPR. Curr. Biol. CB 2016, 26, 2037-2043. [CrossRef]

47. Qureshi, M.A.; Haynes, C.M.; Pellegrino, M.W. The mitochondrial unfolded protein response: Signaling from the powerhouse. J. Biol. Chem. 2017, 292, 13500-13506. [CrossRef]

48. Lu, C.F.; Li, L.Z.; Zhou, W.; Zhao, J.; Wang, Y.M.; Peng, S.Q. Silica nanoparticles and lead acetate co-exposure triggered synergistic cytotoxicity in A549 cells through potentiation of mitochondria-dependent apoptosis induction. Environ. Toxicol. Pharmacol. 2017, 52, 114-120. [CrossRef]

49. Liu, N.; Tang, M. Toxic effects and involved molecular pathways of nanoparticles on cells and subcellular organelles. J. Appl. Toxicol. 2019. [CrossRef]

50. Cao, G.D.; Minami, M.; Pei, W.; Yan, C.H.; Chen, D.X.; O’Horo, C.; Graham, S.H.; Chen, J. Intracellular Bax translocation after transient cerebral ischemia: Implications for a role of the mitochondrial apoptotic signaling pathway in ischemic neuronal death. J. Cereb. Blood Flow Metab. 2001, 21, 321-333. [CrossRef]

51. Gogvadze, V.; Orrenius, S.; Zhivotovsky, B. Multiple pathways of cytochrome c release from mitochondria in apoptosis. BBA-Bioenerg. 2006, 1757, 639-647. [CrossRef] [PubMed]

52. Vosler, P.S.; Graham, S.H.; Wechsler, L.R.; Chen, J. Mitochondrial Targets for Stroke Focusing Basic Science Research Toward Development of Clinically Translatable Therapeutics. Stroke 2009, 40, 3149-3155. [CrossRef] [PubMed]

53. Youle, R.J.; Strasser, A. The BCL-2 protein family: Opposing activities that mediate cell death. Nat. Rev. Mol. Cell Biol. 2008, 9, 47-59. [CrossRef] [PubMed]

54. Gupta, S.; Cuffe, L.; Szegezdi, E.; Logue, S.E.; Neary, C.; Healy, S.; Samali, A. Mechanisms of ER Stress-Mediated Mitochondrial Membrane Permeabilization. Int. J. Cell Biol. 2010, 2010, 170215. [CrossRef] [PubMed]

55. Klee, M.; Pallauf, K.; Alcala, S.; Fleischer, A.; Pimentel-Muinos, F.X. Mitochondrial apoptosis induced by BH3-only molecules in the exclusive presence of endoplasmic reticular Bak. EMBO J. 2009, 28, 1757-1768. [CrossRef]

56. Chen, F.; Lin, P.; Wang, N.; Yang, D.; Wen, X.; Zhou, D.; Wang, A.; Jin, Y. Herp depletion inhibits zearalenone-induced cell death in RAW 264.7 macrophages. Toxicol. Vitr. 2016, 32, 115-122. [CrossRef]

(C) 2019 by the authors. Licensee MDPI, Basel, Switzerland. This article is an open access article distributed under the terms and conditions of the Creative Commons Attribution (CC BY) license (http://creativecommons.org/licenses/by/4.0/). 